\title{
Determining the possible application value of diatoms as indicators of general water quality: A comparison with SASS 5
}

\author{
PA de la Rey*, JC Taylor, A Laas, L van Rensburg and A Vosloo \\ School for Environmental Science and Development, North-West University, Potchefstroom Campus, 2520, South Africa
}

\begin{abstract}
The applicability of a European numerical diatom index, the Specific Pollution sensitivity Index (SPI), was tested in a river system where the SPI scores were compared both to chemical water quality and to scores yielded using a macro-invertebrate index of riverine health namely the South African Scoring System (SASS 5). This investigation showed that the SPI reflects certain elements of water quality with a high degree of accuracy. Due to the broad species base of SPI, few problems were encountered when using this system in the Southern Hemisphere. The conclusion is that SPI or a similar diatom index will provide a valuable addition to the suite of biomonitoring tools currently in use in South Africa.
\end{abstract}

Keywords: biomonitoring, diatoms, SASS 5, SPI diatom index, general water quality

\section{Introduction}

We live on a subcontinent recognised for its unpredictable rainfall. South Africa is a semi-arid country, and the decline in the quality of available water is one of the major problems currently facing the country (Davies and Day, 1998). There are several factors that contribute to the decline in water quality, the most important being industry, intensive and careless agricultural practices and the population explosion, which increases the demand for domestic water supply. The National Water Act 36 of 1998, repealed and replaced over 100 previous acts. The preliminary section of the Act, states, “...water is (to be) protected, conserved, managed and controlled in a sustainable and equitable manner for the benefit of all persons ..."

Under Act 36 of 1998, activities that pollute or degrade water resources require a licence issued by the Department of Water Affairs and Forestry (DWAF). The Act stipulates that “...an applicant may be required to provide an assessment of the likely effect of the proposed activity on the resource quality...". Licences will not be issued for periods longer than 40 years. Provision is made for the periodic review of the licence at intervals that must not exceed 5 years. The important component of this periodic review is that quality monitoring forms an essential part of the conditions of many such water licences.

Biological monitoring techniques have been introduced as part of routine monitoring programmes due to certain shortcomings in standard physical and chemical methods. Because of the difficulty and cost of chemically analysing every potential pollutant in a sample of water, and of interpreting results in terms of impact severity, it makes sense to monitor aquatic biota. Results from biological monitoring are cost effective and the results can be obtained rapidly. The main advantage of a biological approach is that it examines organisms whose exposure to pollutants is continuous. Thus species present in riverine ecosystems reflect both the present and past history of the water quality in the river, allowing

* To whom all correspondence should be addressed.

甶+2718 299-2493; fax:+2718 299-2503; e-mail: drkpadlr@puk.ac.za Received 22 August 2003; accepted in revised form 14 January 2004. detection of disturbances that might otherwise be missed (Eekhout et al., 1996).

Biological communities reflect the overall ecological integrity by integrating various stressors, thus providing a broad measure of their synergistic impacts. Aquatic communities, both plant and animal, integrate and reflect the effects of chemical and physical disturbances that occur over extended periods of time. These communities can provide a holistic and an integrated measure of the integrity or health of the river as a whole (Chutter, 1998).

Numerous methods have been developed for the bioassessment of the integrity of aquatic systems. Some of these are based on one or other aspect of a single species, but most are based on the attributes of whole assemblages of organisms such as fish, algae or invertebrates. Although methods have been available for many years, biomonitoring has only as recently as 1996 become a routine tool in the management of South Africa's inland waters (Hohls, 1996).

Benthic macro-invertebrates are recognised as valuable organisms for bioassessments, due largely to their visibility to the naked eye, ease of identification, rapid life cycle often based on seasons and their largely sedentary habits (Dickens and Graham, 2002). Currently, the backbone of the National River Health Programme is SASS (South African Scoring System), a macro-invertebrate index developed by Chutter (1998). The SASS system has undergone several refinements to suit all conditions; the most recent of these modifications is SASS 5 (Dickens and Graham, 2002). However, Round (1991) lists several reasons why animal components of an ecosystem may not provide a satisfactory index system:

- Animals have complex reproductive cycles which are often linked to the seasons,

- Animals are largely motile and this may cause difficulty during sampling,

- Animals may have many different life stages and may undergo metamorphosis,

- Animals have specific habitats and niches;

- They are actively grazed; and closely linked to flow conditions and thus will not usually be evenly distributed from headwaters to estuaries, and 
- Watercourses, which are too deep to wade across, may prove difficult if not impossible to evaluate using a macro-invertebrate index along the length of the stream.

Finally, the composition of the aquatic invertebrate community is always modified immediately downstream of dams and weirs. This is also often true downstream of bridges (Chutter, 1998) and therefore decreases the potential uses of SASS.

No single group of organisms is always best suited for detecting the diversity of environmental perturbations associated with human activities. If the maintenance of ecosystem integrity is the aim of river management, there is a need to monitor the status of different taxonomic groups. Diatoms provide interpretable indications of specific changes in water quality (Kwandrans et al., 1998), whereas invertebrate and fish assemblages may better reflect the impact of changes in the physical habitat in addition to certain chemical changes (McCormick and Cairns, 1994).

The diatoms (Bacillariophyceae) comprise a ubiquitous, highly successful and distinctive group of unicellular algae, with the most obvious distinguishing characteristic the possession of siliceous cell walls (frustules). As autotrophs, diatoms contribute significantly to the productivity of such ecosystems, frequently forming the base of aquatic food chains (Cox, 1996).

Diatoms are abundant, diverse and important components of algal assemblages in freshwater bodies. They comprise a large portion of total algal biomass over a broad spectrum of trophic states (Kreis et al., 1985). Diatoms are used as biological indicators for a number of reasons:

- They occur in all types of aquatic ecosystems.

- They collectively show a broad range of tolerance along a gradient of aquatic productivity, individual species have specific water chemistry requirements (Werner, 1977; Round, 1991).

- They have one of the shortest generation times of all biological indicators (Rott, 1991). They reproduce and respond rapidly to environmental change and provide early warnings of both pollution increases and habitat restoration success. It takes two to three weeks before changes are reflected to a measurable extent in the assemblage composition (Round, 1991; Kelly et al., 1998).

- They are sensitive to change in nutrient concentrations, (Pan et al., 1996). Each taxon has a specific optimum and tolerance for nutrients such as phosphate (Hall and Smol, 1992; Reavie et al., 1995; Fritz et al., 1993; Bennion, 1994, Bennion et al., 1996) and nitrogen (Christie and Smol, 1993), which can usually be quantified to a high degree of certainty.

- Assemblages are usually diverse and therefore contain considerable ecological information. For this reason, and because it is easy to obtain large numbers of individuals, robust statistical and multivariate procedures can be used to analyze assemblage data. (Dixit et al., 1992).

- They respond rapidly to eutrophication and recovery (e.g.Zeeb et al., 1994). Because diatoms are primarily photoautotrophic organisms, they are directly affected by changes in nutrient and light availability (Tilman et al., 1982).

- Rapid immigration rates and the lack of physical dispersal barriers ensure there is little lag-time between perturbation and response (Vinebrooke, 1996).

- The taxonomy of diatoms is generally well-documented (Krammer and Lange-Bertalot, 1986-91). Species identifications are largely based on frustule morphology.

- Diatoms can be found on substrata in streambeds even when dry, so they can be sampled at most times of the year (Stevenson and Pan, 1999).

Round (1993) lists numerous reasons why diatoms are useful tools of biomonitoring, amongst which the following bear especial relevance to the South African situation; methods are cost- effective, data are comparable, techniques are rapid and accurate, and non-specialists with a biological background can do identifications and counts if they are provided with illustrated guides.

Concern has been expressed about the transfer and comparison of data between the Northern and Southern Hemisphere (Round, 1991). It is well known that some species have the same morphology, but questions still remain concerning the range of ecological tolerances of these various species. This is a valid concern when distance, climatic condition, and other environmental pressures are taken into account. However, Kelly et al., (1998) discuss the concept, that diatoms are 'subcosmopolitan', i.e. they occur anywhere when certain environmental conditions are fulfilled. This concept suggests that geographical location is not the determining factor in the distribution of diatom species and the composition of communities, but it is rather the specific environmental variables at a specific site that determine this distribution.

Diatom indices may be able to provide answers to the problems involved in monitoring rivers for the inorganic nutrients that cause eutrophication, organic loading, ionic composition and dissolved oxygen (Kwandrans et al., 1998).

The aim of the study was to ascertain whether the numerical diatom index developed in Europe has a potential use for indicating general water quality in the North West Province. Bate et al. (2002), in a study on South African rivers, came to the conclusion that benthic diatoms could be a useful addition to the national biomonitoring programme as they give a time-integrated indication of specific water quality components. However, Bate et al. (2002) went on to state that the particular data set tested in their study that of Van Dam et al. (1994), could not be transposed directly to South African conditions. For this reason the current study investigates the potential use of another autecological diatom index developed in Europe (France).

A further aim of the study was to establish whether diatom species are indeed sub-cosmopolitan as stated by Kelly et al., (1998), by determining the number of species actually used in the calculation of the chosen index.

SASS 5 was chosen for comparison as it is widely used in biomonitoring river systems in South Africa and is currently considered as the industry standard for biomonitoring.

\section{Materials and methods}

\section{Sampling sites}

Twelve sampling sites in the Mooi River in the North West province of South Africa were chosen for this study. The study was conducted during May 2003. Study sites were chosen to represent a range of water quality and the impact of some of the tributaries entering the Mooi River. The study sites (Fig. 1) extended from below Klerkskraal Dam (M1; 26³0,86’ S, 2707,40’ E), downstream to the Prozesky Bird Sanctuary in Potchefstroom (M5; $\left.26^{\circ} 34,13^{\prime} \mathrm{S}, 27^{\circ} 06,03^{\prime} \mathrm{E}\right)$. The four tributaries that formed part of the study were the Wonderfontein Spruit (WFS), an unnamed tributary near Boskop Dam (T3), Wasgoed Spruit (WS) in Potchefstroom as well as Loop Spruit (LS) entering the Mooi River at the Prozetsky Bird sanctuary.

Land use in the upper reaches of the Mooi River catchment is 


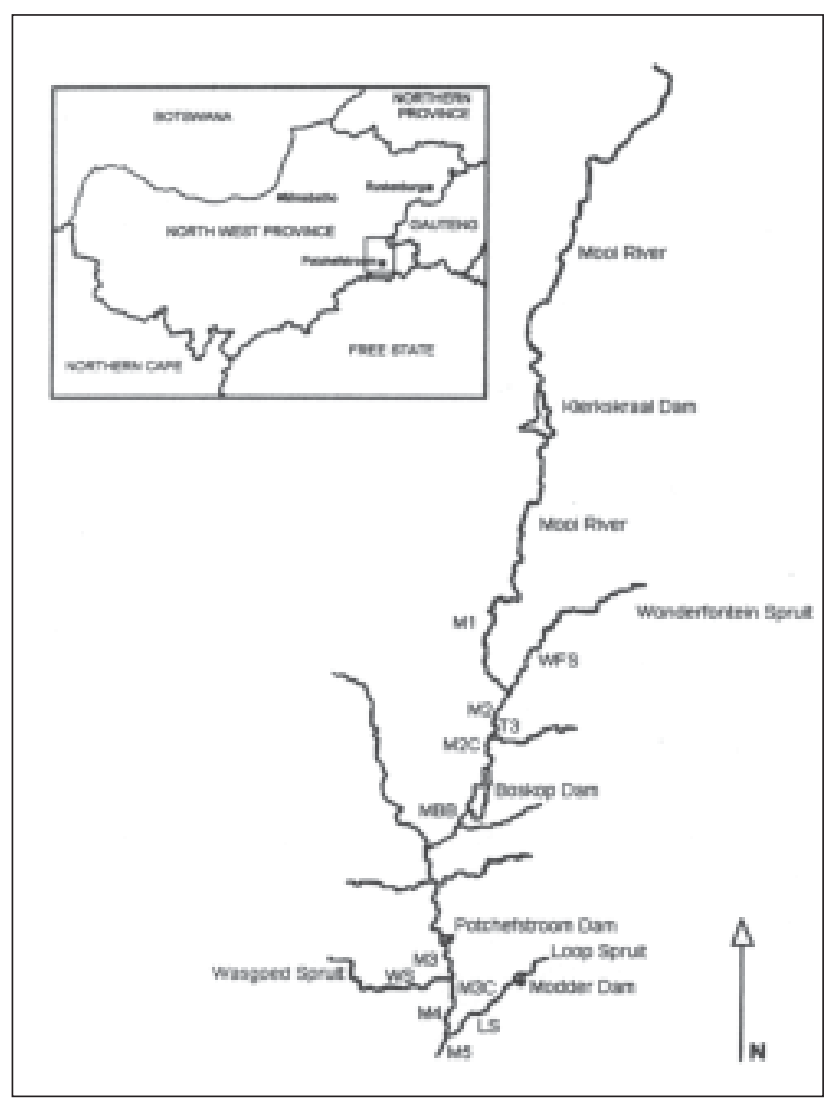

Figure 1

The Mooi River system (North West Province, South Africa) showing the location of the sampling sites used in the study

mainly agricultural with activities such as peat and informal diamond mining occurring further downstream. Gold mining and sewage effluent enters the Mooi River through the Wonderfontein Spruit. The unnamed tributary (T3) introduces water from a canal into the Mooi River just above Boskop Dam, from an unknown source. Effluents from heavy industry (e.g. a fertilizer manufacturer) as well as storm water drain into the Mooi River from Potchefstroom via the Wasgoed Spruit. Loop Spruit is mainly influenced by agricultural activities.

The study also included samples above and below two major dams in the system namely the Boskop Dam and Potchefstroom Dam.

\section{SASS 5 and ASPT scores}

Macro-invertebrates were collected as prescribed by the SASS 5 protocol and the SASS 5 and ASPT (average score per taxon, calculated as the total SASS score divided by the number of taxa contributing to the SASS score) indices calculated according to standard methods (Dickens and Graham (2002); Chutter (1998)).

\section{Diatoms}

\section{Sample collection}

Three to five different boulders at any particular site (Round, 1993) were sampled from different positions within a defined $10 \mathrm{~m}$ reach, in a riffle if possible. As far as possible, boulders ( $>256 \mathrm{~mm}$ ) free of filamentous algae and obvious siltation were selected. The diatoms were removed to provide a composite sample. The diatoms were sampled from the upper surface of the boulder with a stiff toothbrush and the epilithon collected in a $250 \mathrm{~m} \ell$ sample bottle, suspended in distilled water (Kelly et al., 1995).

\section{Preparation and identification}

Samples were allowed to settle for $24 \mathrm{~h}$ and the supernatant decanted. Samples were first examined live to establish if a considerable number of dead cells were present. This was done, as only living cells will be able to provide a reflection of recent water quality. The samples were then oxidised in a saturated solution of potassium permanganate. Carbonates were removed using concentrated (32\%) hydrochloric acid (Pienaar, 1988). Samples were then rinsed with distilled water and collected by centrifugation, using five successive runs at $2500 \mathrm{r} \cdot \mathrm{min}^{-1}$. Clean valves were then mounted in Pleurax (Hanna, 1949).

Diatoms were identified under phase contrast using an oilimmersion lens at $1000 \mathrm{x}$ magnification. The nomenclature follows Krammer and Lange-Bertalot (1986-91). At least 400 valves (400-500) were identified for each sample (Prygiel, 2002).

\section{Description of the SPI diatom index}

The index used is based on the weighted average equation of Zelinka and Marvan (1961) and has the basic form:

$$
\text { index }=\frac{\sum_{j}^{n}=1 a_{j}^{a_{j} v_{j}}}{\sum_{j}^{n}=1 a_{j}^{a_{j}}},
$$

where:

$$
\begin{aligned}
& a_{j}=\text { abundance (proportion) of species } j \text { in sample } \\
& v_{j}=\text { indicator value } \\
& s_{j}=\text { pollution sensitivity of species } j .
\end{aligned}
$$

The performance of the index depends on the values given to the constants $s$ and $v$ for each taxon and the values of the index ranges from 1 to an upper limit equal to the highest value of $s$. For SPI (Specific Pollution sensitivity Index; CEMAGREF, 1982), the maximum value of 5 (converted to 20 by the software package OMNIDIA; Lecointe et al., 1993) indicates clean water. SPI is a comprehensive index, with values of $s$ and $v$ available for over 1300 species (Coste et al., 1991).

\section{Chemical analysis}

Chemical analyses were performed according to Standard Methods (1995) by accredited laboratories namely Mogale City local municipality water laboratory and the Agricultural Research Council: Institute for Soil, Climate and Water, Pretoria.

The following water quality variables were analysed in the water quality laboratories: total nitrogen (total $\mathrm{N}$ ), ammonium $\left(\mathrm{NH}_{4}\right)$, total phosphate (total $\mathrm{P}$ ), chemical oxygen demand (COD), five day biological oxygen demand $\left(\mathrm{BOD}_{5}\right)$, sulphate $\left(\mathrm{SO}_{4}\right)$ and chloride $(\mathrm{Cl})$,

Several variables were determined in-stream with a calibrated temperature/pH/conductivity/oxygen meter (YSI 556 MPS Multimeter, USA) at the time of sampling. These included: temperature (temp.), $\mathrm{pH}$, electrical conductivity (EC), dissolved oxygen $\left(\mathrm{DO}_{2}\right)$ and turbidity.

The variables were chosen to represent general water quality according to the monitoring requirements for domestic and industrial wastewater release (DWAF, 1999). The $\mathrm{BOD}_{5}$ was added to this suite to provide an indication of organic load according to the analysis list of Kwandrans et al. (1998). 


\section{Data analysis}

Correlation and stepwise forward multiple regressions were carried out using STATISTICA version 6. Prior to statistical analysis, the distribution of the water quality data was analyzed for normality (STATISTICA Version 6). Where the data showed a skewed distribution the data were $\log _{10}$ transformed. The SPI diatom index was calculated in the database OMNIDIA (Lecointe et al., 1993).

Multiple regressions were performed on the data to establish if there were any physical or chemical variables that influenced the indices other than the ones that showed clear significant correlations in Table 4. Forward stepwise regression was used for this purpose. This regression method takes the independent variable with the greatest contribution and adds it to the model first. Independent variables are then selected for inclusion based on their incremental contribution over the variable(s) already in the equation. Independent variables that are closely correlated in the correlation matrix may not all be included but rather other variables that also contribute to the variation in the index scores. For this reason this method can give important additional information about the factors that influence the various index scores over and above pure correlations. Adjusted $\mathrm{R}^{2}$ values are used as indicators of the level of success with which the independent variables are able to explain the variation in the index values. This value was chosen as the Adjusted $\mathrm{R}^{2}$ takes into account the sample size as well as the number of variables used (Hair et al., 1998). Since 12 sites may be deemed a relatively small sample size the value will give more reliable confidence values than the $\mathrm{R}$ or $\mathrm{R}^{2}$ values.

In this study the ASPT value (7) for Site M2C was deemed to be an outlier due to its exaggerated residual value by comparison with the other sites. According to Hair et al. (1998) the definition of an outlier, in strict terms, is an observation that has a substantial difference between its actual and predicted values of the dependent variable (a large residual) or between its independent variable values and those of other observations. The objective of denoting outliers is to identify observations that are inappropriate representations of the population from which the sample is drawn, so that they may be discounted or even eliminated from the analysis as unrepresentative. For this reason M2C was not used in the calculation of the correlation matrix nor in the multiple regression for ASPT.

\section{Results and discussion}

The results of the water quality analysis are given in Table 1 . When assessing the water quality data qualitatively, according to the variables tested, it appears that the lowest water quality was observed in the Wasgoed Spruit. The stream contained elevated levels of chloride, sulphate, ammonia and other minerals and displayed the highest electrical conductivity in the system.

The highest levels of biological oxygen demand and sulphate, as well as elevated levels of chemical oxygen demand, chloride and total nitrogen were observed in the Wonderfontein Spruit. The influence of the Wonderfontein Spruit on the Mooi River can be seen when comparing the chemical data from sites M1 and M2. Sulphate levels increased considerably from M1 to M2 due to the confluence of the Mooi River with the Wonderfontein Spruit. Increases in chemical oxygen demand, chloride and total nitrogen were also observed in the Mooi River after the confluence of these two streams.

Table 2 shows the values produced for the various indices for the different sites in the Mooi River catchment. For the interpretation of the various indices limit classes are given in Table 3 and 4. The lowest SASS 5 and ASPT scores were recorded in the Wonderfontein Spruit (WFS) that shows major deterioration in water quality, while the diatom index showed the water to be of moderate quality. The lowest SPI score was recorded in the Wasgoed Spruit (WS), which displays a value that can be interpreted as bad water quality, while SASS 5 and ASPT for the same site show values that indicate only some deterioration in water quality.

From Table 2 it would seem as though the diatom index (SPI) is more sensitive to the elevated physical and chemical parameters (that were measured for this study) in the Wasgoed Spruit than the two other indices tested. This would concur with Willemsen et al. (1990), who in a study of the impact of stormwater in the Netherlands, concluded that diatoms were more sensitive to these discharges than were benthic invertebrates; they attribute this to the inability of diatoms to migrate away from unfavourable conditions and to recolonise when conditions have improved.

SASS 5 showed a very low index value for the Wonderfontein Spruit that can be explained by the influence of organic pollution.

\begin{tabular}{|l|c|c|c|c|c|c|c|c|c|c|c|c|}
\hline \multicolumn{10}{|c|}{ TABLE 1 } \\
\hline \begin{tabular}{l|l} 
Site \\
code
\end{tabular} & Temp. & $\mathbf{O}_{2}$ & EC & $\mathbf{p H}$ & Turbidity & Total P & $\mathbf{C O D}$ & $\mathbf{B O D}_{\mathbf{5}}$ & $\mathbf{N H}_{4}$ & Total N & $\mathbf{C l}$ & $\mathbf{S O}_{4}$ \\
& & & & & & & & & & & & \\
\hline M1 & 16.12 & 13.16 & 408 & 7.67 & 3.20 & 0.18 & 6 & 0.00 & 0.05 & 0.25 & 13.77 & 7.05 \\
WFS & 12.11 & 11.72 & 617 & 7.19 & 2.00 & 0.14 & 46 & 1.70 & 0.04 & 2.20 & 64.61 & 270.99 \\
M2 & 13.10 & 9.59 & 538 & 7.42 & 1.40 & 0.23 & 43 & 0.00 & 0.04 & 1.45 & 40.50 & 158.68 \\
T3 & 20.94 & 10.46 & 668 & 7.30 & 0.60 & 0.22 & 6 & 0.00 & 0.03 & 4.37 & 51.02 & 205.77 \\
M2C & 13.41 & 10.22 & 537 & 7.33 & 1.50 & 0.23 & 25 & 0.00 & 0.03 & 1.69 & 42.40 & 168.10 \\
MBB & 12.49 & 11.12 & 506 & 7.34 & 2.20 & 0.17 & 104 & 0.00 & 0.04 & 1.50 & 26.67 & 87.52 \\
M3 & 15.25 & 10.74 & 518 & 7.37 & 4.87 & 0.22 & 27 & 0.00 & 0.04 & 0.27 & 46.98 & 164.02 \\
WS & 12.65 & 8.08 & 1678 & 6.78 & 8.08 & 0.35 & 37 & 0.14 & 0.84 & 3.84 & 543.43 & 207.24 \\
M3C & 15.53 & 8.84 & 540 & 7.74 & 4.80 & 0.26 & 6 & 0.00 & 0.05 & 0.82 & 60.23 & 180.24 \\
M4 & 15.43 & 10.50 & 541 & 7.00 & 12.40 & 0.15 & 6 & 0.00 & 0.04 & 0.29 & 52.01 & 165.05 \\
LS & 14.16 & 11.76 & 568 & 7.55 & 20.20 & 0.28 & 31 & 0.50 & 0.08 & 2.63 & 55.50 & 199.59 \\
M5 & 16.20 & 12.97 & 554 & 7.23 & 20.20 & 0.17 & 6 & 0.00 & 0.04 & 0.41 & 53.45 & 151.03 \\
\hline
\end{tabular}




\begin{tabular}{|l|c|c|c|}
\hline \multicolumn{4}{|c|}{ TABLE 2 } \\
Recorded scores for SASS 5, ASPT \\
and SPI in the Mooi River (May 2003) \\
\hline Site & SASS 5 & ASPT & SPI \\
code & & & \\
\hline M1 & 116 & 5.50 & 15.2 \\
WFS & 48 & 4.00 & 12.6 \\
M2 & 62 & 5.20 & 13.5 \\
T3 & 96 & 4.80 & 12.4 \\
M2C & 70 & 7.00 & 13.5 \\
MBB & 82 & 4.80 & 14.0 \\
M3 & 89 & 5.20 & 12.6 \\
WS & 80 & 4.44 & 4.5 \\
M3C & 78 & 4.58 & 12.6 \\
M4 & 64 & 4.27 & 9.1 \\
LS & 105 & 4.56 & 12.4 \\
M5 & 80 & 4.71 & 9.9 \\
\hline
\end{tabular}

TABLE 4

Class limit values for SPI (Eloranta \& Soininen, 2002)

\begin{tabular}{|c|c|}
\hline Class & SPI score \\
\hline high quality & $>17$ \\
good quality & 15 to 17 \\
moderate quality & 12 to 15 \\
poor quality & 9 to 12 \\
bad quality & $<9$ \\
\hline
\end{tabular}

According to Dallas and Day (1993) the enrichment of a water body with organic waste almost certainly results in a decrease in invertebrate species richness, diversity and an alteration in the composition of those communities. Chutter (1998) also observed that SASS scores were very low in organically polluted water. SPI scores did not accurately reflect the degree of organic loading in the Wonderfontein Spruit. This can also be seen in the correlation matrix (Table 5), which shows that SPI has no significant correlation to biological oxygen demand.

It is clear from these two sites (WFS and WS) that the various indices do not give the same indication of water quality. This might be due to a difference in response to environmental changes between the different groups of organisms used for calculation of SASS5 and SPI indices. This is a reason for the use of a suite of bioindicators to assess the status of an ecosystem properly. Table 5 shows the correlation matrix of the various indices together with physical and chemical parameters. A significant correlation $(\mathrm{p}<0.05)$ was observed between SASS 5 and ASPT scores. A similar correlation was not observed between the macro-invertebrate indices and the diatom index used. However, a decline in all the indices (Table 2) can be observed from M1 to M5 as would be expected from studying the water quality data (Table 1 ).

SPI was significantly correlated $(\mathrm{p}<0.05)$ with several of the measured water quality variables (Table 5); these included negative correlations with electrical conductivity, chloride and ammonium. A positive correlation was observed between the $\mathrm{pH}$ and the SPI score.
TABLE 3

Interpretation of SASS 5 scores (Chutter, 1998)

\begin{tabular}{|c|l|}
$\begin{array}{c}\text { ASPT } \\
\text { score }\end{array}$ & Class \\
$>6$ & water quality natural; habitat diversity high \\
$>6$ & water quality natural; habitat diversity reduced \\
$<6$ & $\begin{array}{l}\text { border line good/bad water quality. Interpretation } \\
\text { based on extent that SASS }<100, \text { ASPT }<6\end{array}$ \\
$<6$ & $\begin{array}{l}\text { some deterioration in water quality } \\
\text { major deterioration in water quality }\end{array}$ \\
variable
\end{tabular}


TABLE 6

Regression summary for dependent variable: SASS 5

\begin{tabular}{|l|c|c|c|c|c|c|}
\hline \multicolumn{7}{|c|}{$\mathbf{R}=\mathbf{0 . 9 3 3} \mathbf{R}^{2}=\mathbf{0 . 8 5 1}$ Adjusted $\mathbf{R}^{2}=\mathbf{0 . 7 4 1}$} \\
$\mathbf{p}<\mathbf{0 . 0 2 8}$ & \multicolumn{1}{c|}{ Std. Error of estimate: 9.968} \\
\hline & Beta & Std.Err. & B & Std.Err. & $\mathbf{t}(\mathbf{5})$ & p-level \\
\hline Intercept & & & 106.920 & 30.920 & 3.458 & 0.018 \\
SO $_{4}$ & -0.552 & 0.206 & -0.157 & 0.059 & -2.681 & $\mathbf{0 . 0 4 4}$ \\
Total P & 0.745 & 0.232 & 119.363 & 37.139 & 3.214 & $\mathbf{0 . 0 2 4}$ \\
$\mathbf{O}_{2}$ & 0.655 & 0.228 & 8.095 & 2.816 & 2.875 & $\mathbf{0 . 0 3 5}$ \\
COD & -0.230 & 0.168 & -9.575 & 6.975 & -1.373 & 0.228 \\
Total N & 0.296 & 0.219 & 3.950 & 2.927 & 1.349 & 0.235 \\
\hline
\end{tabular}

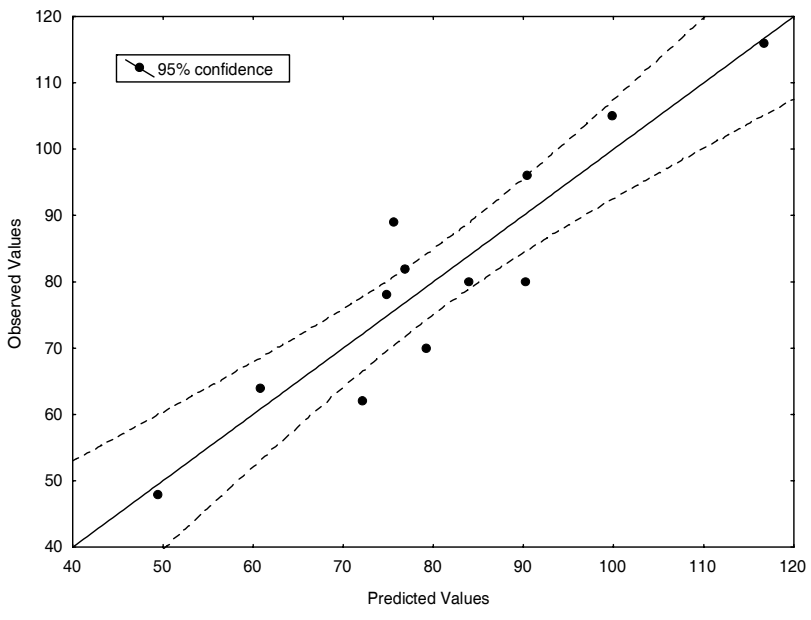

Figure 2

Predicted SASS 5 values vs. observed SASS 5 values

ASPT scores correlated significantly with the biological oxygen demand of the water as well as sulphate levels. Biological oxygen demand indicates the degree of organic loading of a stream (Viessman and Hammer, 1998). SASS 5 index scores did not show any significant correlation with any specific water quality variables. This lack of significant correlation was not unexpected as attempts, which have been made to find direct correlation between SASS4 results and water quality variables have, so far, been unsuccessful (Vos et al., 2002).

Table 6 shows the regression results of the multiple regression performed on the physical and chemical variables and the SASS 5 index scores. From the results it can seen that five of the independent variables were used to account for the variation in the SASS 5 index values. Sulphate, total phosphate and dissolved oxygen all contributed significantly to the variation in the data while COD and total nitrogen also contributed, but not significantly. From the adjusted $\mathrm{R}^{2}$ (Table 6) it is clear that the proposed linear model can successfully account for approximately $74 \%$ of the variation in the index values. This would mean that about $26 \%$ of the variation in the data could not be accounted for by the proposed model and might be accounted for by factors such as habitat.

Figure 2 shows the predicted vs. observed SASS 5 index values. The closer the observations are to the straight line the better the observations could be explained by the proposed multiple regression model. As can be seen from the graph the model was fairly successful in predicting the actual SASS 5 scores.

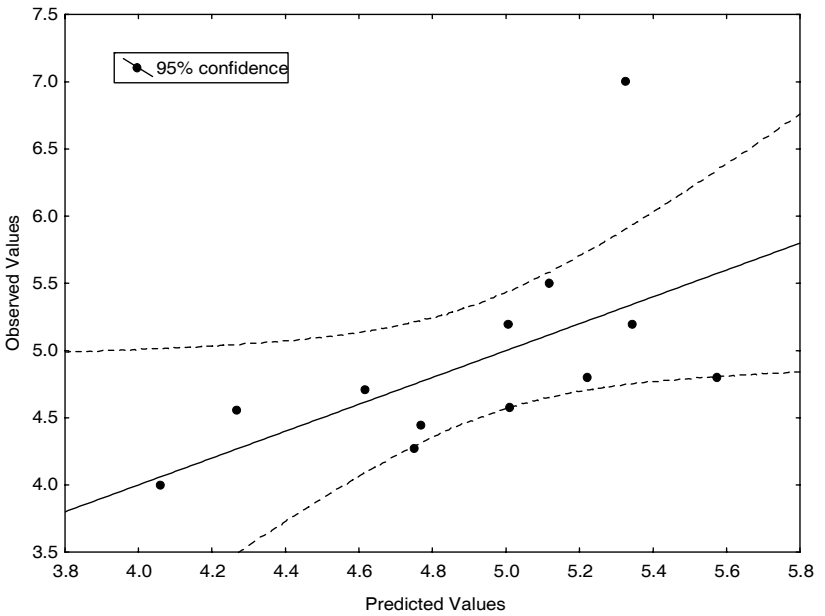

Figure 3

Predicted ASPT values vs. observed ASPT values

Table 7 shows the multiple regression results for the ASPT scores and environmental variables. Four variables were taken into account by the multiple regression for the ASPT scores. Sulphate $(\mathrm{p}<0.05)$ and possibly total phosphate $(\mathrm{p} e \bullet 0.05)$ contributed to the variation in the ASPT scores while ammonia and turbidity also contributed, but not significantly. The model predicted approximately $68 \%$ of the variation in the ASPT scores (Adjusted $\mathrm{R}^{2}$ of 0.678 ).

The graph of predicted vs. observed variables shows that the model was also fairly effective (when compared to the SASS 5 model) in predicting the actual index scores.

The Adjusted $\mathrm{R}^{2}$ (Author to check throughout the doc. whether it should be Adjusted $\mathrm{R}^{2}$ OR adjusted $\mathrm{R}^{2}$ ) for the SPI multiple regression (Table 8 ) is very high with approximately $99 \%$ of the variation in the data explained by various water quality variables. The variables included in the regression model were chloride, $\mathrm{pH}$, turbidity, chemical oxygen demand, sulphate and oxygen. All of the variables except oxygen contributed significantly $(p<0.05)$ to the model.

The graph of predicted vs. observed SPI values (Fig. 4) shows that the model was highly effective in predicting the SPI index values.

A total of 112 diatom species, representing 18 genera, were found in the 12 samples. Of the 112 species encountered only 3 (Psamodictyon constricta (Gregory) DG Mann, Nitzschiaflexoides Geitler and Nitzschia agnita Hustedt) were not relevant to the 
calculation of the SPI index scores. Round (1991) suggested (without experimental evidence) that caution should be observed when transferring index data from the Northern Hemisphere to the Southern Hemisphere as some species may exhibit different ecological tolerances. However, the fact that the SPI values can almost fully be accounted for by the physical and chemical variables in the Mooi River and tributaries (Tables 1 \& 8) should satisfy this concern. In addition, $97 \%$ of the diatom species encountered in this investigation were useful for SPI and hence cosmopolitan in nature.

\section{Conclusions}

According to our results, the diatom index is sensitive to changes in electrical conductivity, ammonia, chemical oxygen demand, chloride, sulphate and turbidity. From this we can conclude that SPI gives a good reflection of general water quality. It would seem as though SPI is able to give a more accurate reflection of the ionic composition of water than the macro-invertebrate index. This is indicated by the strong correlation between electrical conductivity and SPI. Chutter (1998) states that SASS is less sensitive to increases in total dissolved solids (total dissolved solids = electrical conductivity x 6.5 on average) than to other types of chemical change.

From the correlation matrix (Table 5) and the multiple regressions (Tables 6 to 8) it can be deduced that the diatom index is more closely influenced by water quality than the ASPT or the SASS 5 indices. It seems that the macro-invertebrate indices cannot be fully explained by the water quality variables used in this study and may also be affected by other factors such as habitat diversity or other water quality variables not included.

There is therefore, still a need for a biological indicator (such as the diatom index used in this study) that can be indicative of specific water quality variables.

The fact that the diatom sampling also has fewer restrictions in terms of habitat requirements than macro-invertebrates could facilitate its use in monitoring water quality in small tributaries, for instance mining and industrial effluent. This conclusion is strengthened by Round's (2001) statement that "...river diatoms can colonize massive rivers but also "rivers" millimetres deep and centimetres wide..."

From the results of this study it would seem fair to say that there is definite potential for the use of numerical diatom indices as indicators of general water quality and the usefulness of these indices should be verified by further studies that cover a broader geographical area and a broader range of variables.

\section{Acknowledgements}

The authors gratefully acknowledge the comments provided by Prof KN de Kock (School for Environmental Sciences and development, North-West University, Potchefstroom Campus) as well as the assistance provided by Mrs T de la Rey (School for Computer, Statistical and Mathematical Sciences, North-West University, Potchefstroom Campus) with the statistical analysis.
TABLE 7

Regression summary for dependent variable: ASPT

$R=0.898 R^{2}=0.807$ Adjusted $R^{2}=0.678$

$F(4,6)=6.272 p<0.025$ Std.Error of estimate: 0.249

\begin{tabular}{|c|c|c|c|c|c|}
\hline eta & Std.Err. & B & Std.Err. & $\mathbf{t}(5)$ & p-level \\
\hline & & 6.549 & 0.551 & 11.896 & 0.000 \\
.781 & 0.183 & -0.005 & 0.001 & -4.260 & $\mathbf{0 . 0 0 5}$ \\
.599 & 0.252 & 2.151 & 0.903 & 2.381 & $\mathbf{0 . 0 5 5}$ \\
.427 & 0.264 & -0.466 & 0.289 & -1.614 & 0.158 \\
198 & 0.192 & -0.178 & 0.173 & -1.028 & 0.344 \\
\hline
\end{tabular}

TABLE 8

Regression Summary for Dependent Variable: SPI

$R=0.998 R^{2}=0.995$ Adjusted $R^{2}=0.990$

$F(6,5)=174.740 p<0.00001$ Std.Error of estimate: 0.291

\begin{tabular}{|c|c|c|c|c|c|}
\hline Beta & Std.Err. & B & Std.Err. & $\mathbf{t}(5)$ & p-level \\
\hline & & -16.604 & 4.877 & -3.405 & 0.019 \\
-0.609 & 0.078 & -4.705 & 0.605 & -7.777 & $\mathbf{0 . 0 0 1}$ \\
0.428 & 0.047 & 4.563 & 0.497 & 9.183 & $\mathbf{0 . 0 0 0}$ \\
-0.238 & 0.041 & -1.400 & 0.240 & -5.827 & $\mathbf{0 . 0 0 2}$ \\
0.195 & 0.033 & 1.230 & 0.205 & 5.990 & $\mathbf{0 . 0 0 2}$ \\
0.141 & 0.042 & 0.006 & 0.002 & 3.372 & $\mathbf{0 . 0 2 0}$ \\
0.071 & 0.052 & 0.133 & 0.097 & 1.380 & 0.226 \\
& & & & & \\
\hline
\end{tabular}

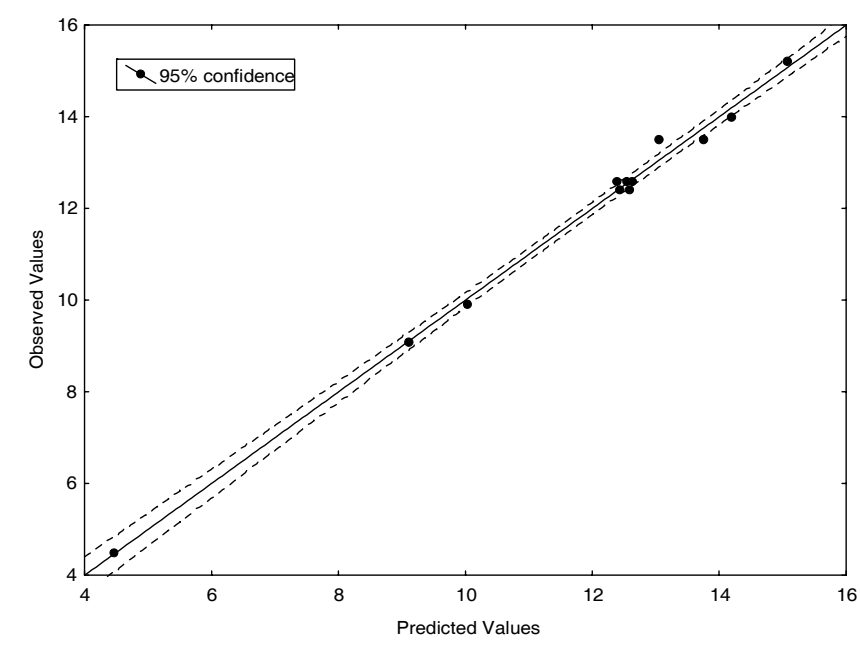

Figure 4

Predicted SPI values vs. observed SPI values

\section{References}

BATE GC, ADAMS JB and VAN DER MOLEN JS (2002) Diatoms as Indicators of Water Quality in South African River Systems. WRC Report No 814/1/02. Water Research Commision. Pretoria. 164 pp. BENNION H (1994) A diatom-phosphorus transfer-function for shallow, eutrophic ponds in Southeast England. Hydrobiol. 275/276 391-410.

BENNION H, JUGGINS S, and ANDERSON NJ (1996) Predicting epilimnetic phosphorus concentrations using an improved diatom- 
based transfer function and its application to lake management Environ. Sci. Technol. 30 2004-2007.

CEMAGREF (1982) Etude des méthodes biologiques quantitatives d'appréciation de la qualité des eaux. Rapport Division Qualité des Eaux Lyon. Agence financiè de Bassin Rhone-Méditerarée. Corse, Pierre-Bénite $28 \mathrm{pp}$.

CHRISTIE CE and SMOL JP (1993) Diatom assemblages as indicators of lake trophic status in south eastern Ontario lakes. J. Phycol. 29 575-586

CHUTTER FM (1998) Research on the Rapid Biological Assessment of Water Quality Impacts in Streams and Rivers. WRC Report No 422/ 1/98. Water Research Commission. Pretoria.

COSTE M, BOSCA C and DAUTA A (1991) Use of algae for monitoring rivers in France. In: WHITTON BA, ROTT E and FRIEDRICH G (eds.) Use of Algae for Monitoring Rivers. E. Rott, Institüt für Botanik, Univ. Innsbruk. 75-88.

COX EJ (1996) Identification of Freshwater Diatoms from Live Material. Chapman \& Hall. London.

DALLAS HF and DAY JA (1993) The Effect of Water Quality on Riverine Ecosystems: A Review. WRC Report No TT 61/93. Water Research Commission. Pretoria.

DAVIES B and DAY J (1998) Vanishing Waters. University of Cape Town Press. University of Cape Town. Rondebosch. 487 pp.

DEPARTMENT OF WATER AFFAIRS AND FORESTRY (DWAF) (1999) General authorizations in terms of Section 39 of the Nationa Water Act, 1998 (Act no 36 of 1998). Government Gazette No 20526.

DICKENS CWS and GRAHAM M (2002) The South African Scoring System (SASS) Version 5 rapid bio-assessment method for rivers. Afr. J. Aquat. Sci. 27 1-10.

DIXIT SS, SMOL JP, KINGSTON JC and CHARLES DF (1992) Diatoms Powerful indicators of environmental change. Environ. Sci. Technol. 26 23-33.

EEKHOUT S, BROWN CA and KING JM (1996) National Biomonitoring Programme for Riverine Ecosystems: Technical Considerations and Protocol for the Selection of Reference and Monitoring Sites. NBP Report Series No.3. Institute for Water Quality Studies, Department of Water Affairs and Forestry, Pretoria.

FRITZ SC, KINGSTON JC and ENGSTROM DR (1993) Quantitative trophic reconstructions from sedimentary diatom assemblages: A cautionary tale. Freshwater Biol. 30 1-23.

HAIR JF (Jr), ANDERSON RE, TATHAM RE and BLACK W (1998) Multivariate Data Analysis. Prentice-Hall, New Jersey.

HALL RI, and SMOL JP (1992) A weighted-averaging regression and calibration model for inferring total phosphorus concentration from diatoms in British Columbia (Canada) lakes. Freshwater Biol. 27 417-434.

HANNA GD (1949) A synthetic resin which has unusual properties. J.R Microb. Soc. 69 25-28

HOHLS DR (1996) National Biomonitoring Programme for Riverine Ecosystems: Framework Document for the Programme. NBP report series No. 1. Institute for Water Quality Studies, Department of Water Affairs and Forestry, Pretoria.

KELLY MG, PENNY CJ and WHITTON BA (1995) Comparative performance of benthic diatom indices used to assess river water quality. Hydrobiol. 302 179-188.

KELLY MG, CAZAUBON A, CORING E, DELL'UMO A, ECTOR L, GOLDSMITH B, GUASCH H, HÜRLIMANN J, JARLMAN A, KAWECKA B, KWANDRANS J, LAUGASTE R, LINSTRØM EA, LEITAO M, MARVAN P, PADISÁK J, PIPP E, PRYGIEL J, ROTT E, SABATER S, VAN DAM H and VIZINET J (1998) Recommendations for the routine sampling of diatoms for water quality assessments in Europe. J. Appl. Phycol. 10 215-224.

KRAMMER K and LANGE-BERTALOT H (1986-1991) Bacillariophyceae. Süßwasserflora von Mitteleuropa 2 (1-4). Spektrum Akademischer Verlag, Heidelberg. Berlin.

KREIS RG, STOERMER EF and LADEWSKI TB (1985) Phytoplankton Species Composition, Abundance, and Distribution in Southern Lake Huron, 1980; Including a Comparative Analysis with Conditions in 1974 Prior to Nutrient Loading Reductions. Great Lakes Research
Division Special Report no. 107. Ann Arbor, MI: The University of Michigan.

KWANDRANS J,ELORANTAP, KAWECKA B and W KRYZSYSZTOF W (1998) Use of benthic diatom communities to evaluate water quality in rivers of southern Poland. J. Appl. Phycol. 10 193-201.

LECOINTE C, COSTE M and PRYGIEL J (1993) "Omnidia": Software for taxonomy, calculation of diatom indices and inventories management. Hydrobiol. 269/270 509-513.

McCORMICK PV and CAIRNS JR J (1994) Algae as indicators of environmental change. J. Appl. Phycol. 6 509-526

PAN Y, STEVENSON RJ, HILL BH, HERLIHY AT and COLLINS GB (1996) Using diatoms as indicators of ecological conditions in lotic systems: A regional assessment. J. North Am. Benthol. Soc. 15 481495.

PIENAAR C (1988) The Centric Diatom Flora of the Vaal River. Unpublished M.Sc. thesis, University of the Orange Free State, Bloemfontein.

PRYGIEL J (2002) Management of the diatom monitoring networks in France. J. Appl. Phycol. 14 19-26.

REAVIE ED, HALL RI and SMOL JP (1995) An expanded weightedaveraging model for inferring past total phosphorus concentrations from diatom assemblages in eutrophic British Columbia (Canada) lakes. J. Paleolimnol. 14 49-67.

ROTT E (1991) Methodological aspects and perspectives in the use of periphyton for monitoring and protecting rivers. In: WHITTON BA, ROTT E and FRIEDRICH G (eds.) Use of Algae for Monitoring Rivers. E. Rott, Institüt für Botanik, Univ. Innsbruk. 9-16.

ROUND FE (1991) Diatoms in river water-monitoring studies. J. Appl. Phycol. 3 129-145.

ROUND FE (1993) A Review and Methods for the Use of Epilithic Diatoms for Detecting and Monitoring Changes in River Water Quality. Methods for the examination of water and assosiated materials. HMSO Publications. London.

ROUND FE (2001) How large is a river? The view from a diatom. Diatom Res. 16 (1) 105-108.

STANDARD METHODS (1995) Standard Methods for the Examination of Water and Wastewater. APHA United Book Press, Inc., Baltimore, Maryland.

STEVENSON R and PAN Y (1999) Assessing environmental condition in rivers and streams with diatoms. In: STOERMER EF and SMOL JP (1999) The Diatoms: Applications for the Environmental and Earth Sciences. Cambridge University Press, Cambridge. 11-40.

TILMAN D, KILHAM SS and KILHAM P (1982) Phytoplankton community ecology: The role of limiting nutrients. Ann. Rev. Ecol. Syst. 13 349-372.

VAN DAM H, MERTENS A and SINKELDAM J (1994) A coded checklist and ecological indicator values of freshwater diatoms from the Netherlands. Netherlands J. Aquat. Ecol. 28 (1) 117-133.

VIESSMAN W JR and HAMMER M (1998) Water Supply and Pollution Control. Addison-Wesely, California. $827 \mathrm{pp}$.

VINEBROOKE RD (1996) Abiotic and biotic regulation of periphyton in recovering acidified lakes. J. North Am. Benthol. Soc. 15 318-331.

VOS P, WEPENER V and CYRUS DP (2002) Efficiency of the SASS4 rapid bioassessment protocol in determining river health: A case study on the Mhlathuze River, KwaZulu-Natal, South Africa. Water SA 28 (1) $13-22$.

WERNER D (ed.) (1977) The Biology of Diatoms. University of California Press. Berkeley, CA.

WILLEMSEN GD, GAST HF, FRANKEN ROG and CUPPEN JGM (1990) Urban storm water discharges: effects upon communities of sessile diatoms and macro-invertebrates. Water Sci. Technol. 22147 154.

ZEEB BA, CHRISTIE CE, SMOL JP, FINDLAY DL, KLING H and BIRKS HJB (1994) Responses of diatom and chrysophyte assemblages in Lake 227 sediments to experimental eutrophication. Can. J. Fish. Aquat. Sci. 51 2300-2311.

ZELINKA M and MARVAN P (1961) Zur Präzisierung der biologischen Klassifikation der Reinheit fliessender Gewässer. Archiv. Hydrobiol. 57 389-407. 